\title{
For how long does the quality and quantity of residues in the soil affect the carbon compartments and $\mathrm{CO}_{2}-\mathrm{C}$ emissions?
}

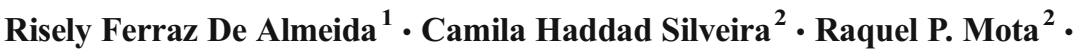 \\ Mara Moitinho ${ }^{1} \cdot$ Everton Martins Arruda $^{2} \cdot$ Eduardo De Sá Mendonça $^{3}$ • \\ Newton La Scala ${ }^{1} \cdot$ Beno Wendling ${ }^{2}$
}

Received: 15 August 2015 / Accepted: 6 April 2016/Published online: 28 April 2016

(C) Springer-Verlag Berlin Heidelberg 2016

\begin{abstract}
Purpose The mineralization/immobilization of nutrients from the crop residues is correlated with the quality of the plant material and carbon compartments in the recalcitrant and labile soil fractions. The objective of this study was to correlate the quality and quantity of crop residues incubated in the soil with carbon compartments and $\mathrm{CO}_{2}-\mathrm{C}$ emission, using multivariate analysis.

Materials and methods The experiment was conducted in factorial $4+2+5$ with three replicates, referring to three types of residues (control, sugarcane, Brachiaria, and soybean), and two contributions of the crop residues in constant rate, CR (10 $\mathrm{Mg} \mathrm{ha}^{-1}$ residue), and agronomic rate, AR (20, 8, and 5 $\mathrm{Mg} \mathrm{ha}^{-1}$ residue, respectively, for sugarcane, soybean, and Brachiaria), evaluated five times (1, 3, 6, 12, and 48 days after incubation). At each time, we determined the $\mathrm{CO}_{2}$ - $\mathrm{C}$ emission, nitrogen and organic carbon in the soil, and the residues. In addition, the microbial biomass and water-soluble, labile, and humic substance carbons fractionated into fulvic acids, humic acids and humin were quantified.
\end{abstract}

Responsible editor: Zucong Cai

Risely Ferraz De Almeida

rizely@gmail.com

1 Universidade Estadual Paulista "Júlio de Mesquita Filho"—UNESP, Campus Jaboticabal/SP End: Via de Acesso Prof. ${ }^{\circ}$ Paulo Donato Castellane, sn, Jaboticabal, SP CEP: 14.884-900, Brazil

2 Instituto de Ciências Agrárias, Universidade Federal de Uberlândia, Uberlândia, MG 38400-902, Brazil

3 Departamento de Produção Vegetal, Centro de Ciências Agrárias, Universidade Federal do Espírito Santo, Alegre, ES CEP: 29500-000, Brazil
Results and discussion Higher $\mathrm{CO}_{2}-\mathrm{C}$ emissions occurred in the soil with added residue ranging from 0.5 to $1.1 \mathrm{~g} \mathrm{CO}_{2}-\mathrm{C}$ $\mathrm{m}^{-2} \mathrm{~h}^{-1}$ in the first 6 days of incubation, and there was a positive correlation with the less labile organic soil fractions as well as residue type. In the final period, after 12 days of soil incubation, there was a higher relation of $\mathrm{CO}_{2}-\mathrm{C}$ emission with carbon humin. The sugarcane and soybean residue $\left(20 \mathrm{Mg} \mathrm{ha}^{-1}\right)$ promoted higher $\mathrm{CO}_{2}-\mathrm{C}$ emission and the reduction of carbon residue. The addition of residue contributed to an $82.32 \%$ increase in the emission of $\mathrm{CO}_{2}-\mathrm{C}$, being more significant in the residue with higher nitrogen availability. Conclusions This study shows that the quality and quantity of residue added to soil affects the carbon sequestration and $\mathrm{CO}_{2}-\mathrm{C}$ emission. In the first 6 days of incubation, there was a higher $\mathrm{CO}_{2}-\mathrm{C}$ emission ratio which correlates with the less stable soil carbon compartments as well as residue. In the final period of incubation, there is no effect of quality and quantity of residue added to soil on the $\mathrm{CO}_{2}-\mathrm{C}$ emission.

Keywords Multivariate analysis $\cdot$ Residue $\cdot$ Soil carbon pools $\cdot$ Soil respiration

\section{Introduction}

The no-till system has been a conservative management system used since 1970 in Brazil (Embrapa 2010), one of the leaders in the use of this system, which occupies more than half of its area planted with annual crops (Mapa 2014). Studies have shown significant ecological, economic, environmental, and social benefits of this system in maintaining crop residue (stubble, pointers, and green leaves) on the ground (Heinz et al. 2011). 
The residues added to the soil surface help to increase the organic matter (SOM), an important source of soil organic carbon (TOC-S), and that, when decomposed/mineralized, releases large amounts of nutrients (Balota et al. 2014) and $\mathrm{CO}_{2}$ via microbial activity (Gassen and Gassen 1996). With the addition of residue, $\mathrm{C}$ sequestration in the soil also occurs (Bordonal et al. 2013), mitigating the concentration of greenhouse gases (GHG) (Alvaro-Fuentes and Paustian 2011), mainly carbon dioxide $\left(\mathrm{CO}_{2}\right)$ (Glaser et al. 2001; Lehmann et al. 2011).

The main crops used in no-till systems are grasses or legumes, among them sugarcane (Saccharum officin arum), soybean (Glycine max), and Brachiaria (Brachiaria decumbens). These materials differ in chemical composition, specifically regarding free sugars, fructans, starch, pectin, hemicellulose, cellulose (Gunnarsson et al. 2008), and lignin (Trinsoutrot et al 2000; Wang et al. 2004), besides the N content and their $\mathrm{C} / \mathrm{N}$ ratio (Trinsoutrot et al. 2000; Moritsuka et al. 2004; Six et al. 2006; Dorodnikov et al. 2011), leading to different decomposition times. The material quality is one of the most important parameters in nutrient dynamics in agricultural soils (Lal 2004), besides the amounts added. The real benefits of the no-till system to increase and sequester $\mathrm{C}$ have recently been questioned (Baker et al. 2007) since it will depend on the quality or quantity of the residue added to soil.

Thus, the aim of this study was to correlate, using multivariate analysis, the influence of time and the quality and quantity of different types of residues incubated on carbon sequestration and $\mathrm{CO}_{2}-\mathrm{C}$ emission from the soil.

\section{Materials and methods}

\subsection{Soil sampling and analysis}

The experiment was conducted at the Pedology Laboratory, Federal University of Uberlândia, Brazil. A factorial $4+2+5$ was established with three replicates, referring to three types of residues (control, sugarcane, Brachiaria, and soybean), and two contributions of the crop residues at constant rate, $\mathrm{CR}$ (10 $\mathrm{Mg} \mathrm{ha}^{-1}$ residue), and agronomic rate, $\mathrm{AR}(20,8$, and $5 \mathrm{Mg} \mathrm{ha}^{-1}$ residue, respectively, for sugarcane, soybean, and Brachiaria), in five different times (1, 3, 6, 12, and 48 days after incubation). In addition, we analyzed the control treatment (soil without residue input).

The residue contributions added to soil have the objective of assessing the quality of the plant material at a $\mathrm{CR}$ of $10 \mathrm{Mg}$ $\mathrm{ha}^{-1}$. The objective of the AR is to evaluate the effect of the quantity with the average contribution of sugarcane, soybean, and Brachiaria residue to the soil. For this, Eq. 1 was used. In this equation, the sum of the agronomic rate (AR) of sugarcane $\left(20 \mathrm{Mg} \mathrm{ha}^{-1}\right)$, soybean $\left(8 \mathrm{Mg} \mathrm{ha}^{-1}\right)$, and Brachiaria $\left(5 \mathrm{Mg} \mathrm{ha}^{-1}\right)$ is subtracted from the number of residues (3) and then divided by the number of residues (3).

$C R=A R_{\text {sugarcane }}+$ soybean + brachiaria $-N / N$

The soil was collected in June 2013 in the $0.0-20.0 \mathrm{~cm}$ layer from an area cultivated with sugarcane under a Dystrophic Red-Yellow Latosol, loamy texture located between the cities of Uberlândia and Uberaba in the Triângulo Mineiro (latitude $19^{\circ} 13^{\prime} 00.22^{\prime \prime} \mathrm{S}$ and longitude $48^{\circ} 08^{\prime} 24.80^{\prime \prime}$ W). In the laboratory, the soil was air-dried, sieved $(<2 \mathrm{~mm})$ to obtain fine air-dried soil (FADS), and moistened to $60 \%$ of its water holding capacity (WHC) for the experiment setup.

For characterization, a soil fraction was utilized for the determination of chemical and physical properties. The soil texture was measured using the pipette method. Potassium $\left(\mathrm{K}^{+}\right)$, calcium $\left(\mathrm{Ca}^{2+}\right)$, magnesium $\left(\mathrm{Mg}^{2+}\right), \mathrm{pH}$ (soluble in $\mathrm{H}_{2} \mathrm{O}$ ), and available phosphorus (P) were measured using the methodologies described by Embrapa (1997). The total nitrogen content of the soil $(\mathrm{N}-\mathrm{S})$ and residue $(\mathrm{N}-\mathrm{St})$ were determined according to the Kjeldahl method using the methodologies of Embrapa (1997) and total organic carbon (TOC$\mathrm{St}$ ) and residue (TOC-St) by the method suggested by Yeomans and Bremner (1988) (Table 1).

The value of lignin (\%) was obtained in Costa et al. (2013), Santos et al (2004), and Reddy and Yang (2009), respectively, for sugarcane, Brachiaria, and soybean residues. The cellulose value (\%) was obtained in Almeida et al. (2009), Gonçalves et al (2007), and Reddy and Yang (2009) and crude protein value (\%) in Pereira et al (2000), Santos et al (2004), and Maheri-Sis et al (2011), respectively, for sugarcane, Brachiaria, and soybean residues.

During the time of the residue sampling (sugarcane, Brachiaria decumbens, and soybean), no distinction was made between stem and leaves in order to obtain a homogeneous sample, and the moisture retention of the material was not considered. In the laboratory, the samples were cut to an average size of $2 \mathrm{~cm}^{2}$ and placed in an oven at $60{ }^{\circ} \mathrm{C}$ for $48 \mathrm{~h}$ for subsequent analyses and incubation.

\subsection{Soil incubation}

For incubation, a column of $700 \mathrm{~g}$ of soil, reaching a height of $13 \mathrm{~cm}$, was placed in a 15-cm-height, 10.5 -cm-diameter PVC (polyvinylchloride) pot and total volume of $1298.8 \mathrm{~cm}^{3}$ fixed on a Styrofoam base properly insulated to prevent soil water loss.

The setup was left in an open laboratory environment at a controlled temperature of $25^{\circ} \mathrm{C}$. This temperature is appropriate for microbial activity (Stanford et al. 1973) since the 
Table 1 Chemical and physical characteristics of sugarcane, Brachiaria, and soybean residues and Red-Yellow Latosol used in the experiment

\begin{tabular}{|c|c|c|c|c|}
\hline \multirow[t]{2}{*}{ Characteristics ${ }^{\mathrm{a}}$} & \multirow[t]{2}{*}{ Soil } & \multicolumn{3}{|l|}{ Residue } \\
\hline & & $\mathrm{SC}$ & $\mathrm{BR}$ & SO \\
\hline Sand $\left(\mathrm{g} \mathrm{kg}^{-1}\right)$ & 630 & - & - & - \\
\hline Silt $\left(\mathrm{g} \mathrm{kg}^{-1}\right)$ & 140 & - & - & - \\
\hline Clay $\left(\mathrm{g} \mathrm{kg}^{-1}\right)$ & 230 & - & - & - \\
\hline $\mathrm{pH}\left(\mathrm{H}_{2} \mathrm{O}\right)$ & 5.60 & - & - & - \\
\hline $\mathrm{P}\left(\mathrm{mg} \mathrm{dm}^{-3}\right)$ & 2.47 & - & - & - \\
\hline $\mathrm{K}^{+}\left(\mathrm{mg} \mathrm{dm}^{-3}\right)$ & 208.08 & - & - & - \\
\hline $\mathrm{Mg}^{2+}\left(\mathrm{cmol}_{\mathrm{c}} \mathrm{dm}^{-3}\right)$ & 0.56 & - & - & - \\
\hline $\mathrm{Ca}^{2+}\left(\mathrm{cmol}_{\mathrm{c}} \mathrm{dm}^{-3}\right)$ & 2.20 & - & - & - \\
\hline TN $\left(\mathrm{N}-\mathrm{St}\right.$ or N-S) $\left(\mathrm{g} \mathrm{kg}^{-1}\right)$ & 0.69 & 1.44 & 1.68 & 2.49 \\
\hline TOC $\left(\mathrm{N}-\mathrm{St}\right.$ or N-S) $\left(\mathrm{g} \mathrm{kg}^{-1}\right)$ & 7.40 & 120.00 & 122.40 & 142.12 \\
\hline $\mathrm{C} / \mathrm{N}$ & - & 83.63 & 72.85 & 50.22 \\
\hline Lignin $(\%)$ & & $25.80^{(4)}$ & $12.76^{(6)}$ & $14.0^{(2)}$ \\
\hline Cellulose $(\%)$ & & $72.90^{(1)}$ & $29.71^{(7)}$ & $44.00^{(2)}$ \\
\hline Crude protein $(\%)$ & & $2.50^{(5)}$ & $2.80^{(6)}$ & $5.10^{(3)}$ \\
\hline
\end{tabular}

${ }^{a}$ In table: $S C$ sugarcane, $S O$ soybean, $B R$ Brachiaria decumbens; potassium $\left(\mathrm{K}^{+}\right)$; calcium $\left(\mathrm{Ca}^{2+}\right)$; magnesium $\left(\mathrm{Mg}^{2+}\right) ; \mathrm{pH}\left(\mathrm{H}_{2} \mathrm{O}\right)$; phosphorus $(\mathrm{P})$; total nitrogen $(\mathrm{TN})$ content of the soil $(\mathrm{N}-\mathrm{S})$ and residue $(\mathrm{N}-\mathrm{St})$ and total organic carbon (TOC) content of the soil (TOC-S) and residue (TOC-St); C/N: relationship between soil organic carbon (TOC and TOC-St) and nitrogen total nitrogen content of the soil (N-S and N-St). (1) Almeida et al. 2009; ${ }^{(2)}$ Reddy and Yang 2009; ${ }^{(3)}$ Maheri-Sis et al. 2011; ${ }^{(4)}$ Costa et al. 2013; ${ }^{(5)}$ Pereira et al. 2000; ${ }^{(6)}$ Santos et al. 2004;

(7) Gonçalves et al. 2007

temperature and humidity of the soil contribute to the increase in soil biological activity (Almeida et al. 2009).

For incubation of the sugarcane residue in the soil, $17.31 \mathrm{~g}$ pot $^{-1}$ of residue corresponding to $20 \mathrm{Mg} \mathrm{ha}^{-1}$ was added, equivalent to an average deposition of between 10 and $30 \mathrm{Mg} \mathrm{ha}^{-1}$ year $^{-1}$ of dry matter on the soil surface in a mechanized planting system (Urquiaga et al. 1991) composed of pointers and green leaves cut to a size of 10-12 cm (Oliveira et al. 1999).

In the treatment with soybean residue, $6.92 \mathrm{~g} \mathrm{pot}^{-1}$ was added, related to the input of $8 \mathrm{Mg} \mathrm{ha}^{-1}$. Soybean cultivation provides low dry matter contribution to the soil surface (Embrapa-Empresa Brasileira de Pesquisa Agropecuária 2014), ranging from 4.81 to $2.81 \mathrm{Mg} \mathrm{ha}^{-1}$, consisting of stems, petiole, trifoliate leaves, and pods (Kurihara et al. 2013).

The input of $5 \mathrm{Mg} \mathrm{ha}^{-1}$ of Brachiaria pasture residue (Brachiaria decumbens) was obtained with the addition of $4.32 \mathrm{~g} \mathrm{pot}^{-1}$ of dry residue. The average Brazilian covering dry matter production of Brachiaria decumbens is $6.0 \mathrm{Mg}$ $\mathrm{ha}^{-1}$ (Torres et al. 2005; Rossi et al. 2011) and can range from 4.8 to $11.17 \mathrm{Mg} \mathrm{ha}^{-1}$ (Nunes et al. 2006).

To evaluate the quality of plant material, we added the same dose of $10 \mathrm{~g} \mathrm{pot}^{-1}$ for all types of residue related to input of $11.57 \mathrm{Mg} \mathrm{ha}^{-1}$. After setting, 120 plots were maintained at $60 \%$ of field capacity during the experiment. The water content was kept constant by monitoring the weight of the pots to assure optimum microbial activity in the studied treatments (Barros 2012).

\subsection{Emission of $\mathrm{CO}_{2}-\mathrm{C}$ and soil $\mathrm{C}$ compartments}

Evaluation of $\mathrm{CO}_{2}-\mathrm{C}$ emissions from the soil were conducted at $1,2,3,4,6,8,10,13,16,19,22,25,28,31,34,37,44$, and 48 days after incubation (DAI), using a portable infrared gas analyzer system. This instrument consists of a closed chamber with an internal volume of $854.2 \mathrm{~cm}^{3}$ and ground contact area of $83.7 \mathrm{~cm}^{2}$ (LI 8100; Li-Cor Inc., Lincoln, NE, USA). After closing, the system quantifies the variations in the concentration of $\mathrm{CO}_{2}-\mathrm{C}$ within the chamber over time by optical absorption spectroscopy in the infrared spectral region.

On the 1st, 3rd, 6th, 12th, and 48th day after incubation, respectively, the 24 setups with all the soil sampling treatments were dismantled. They were subsequently sieved in a 2-mm mesh, homogenized, and the remaining residue separated. With the soil still damp, the measurement of soil microbial biomass carbon (C-Mic) was conducted by the method described by Vance et al. (1987) using a microwave oven for irradiation (Islam and Weil 1998).

After drying the samples, soil organic carbon (TOC-S) and residue (TOC-St) were determined using oxidation with potassium dichromate method in acid medium (Yeomans and Bremner 1988). It should be noted that for characterizing the soil and residue TOC before incubation, we used the same method.

The water-soluble carbon (C-WSC) was extracted with deionized water. For carbon oxidation, we followed the procedures recommended by Yeomans and Bremner (1988). The quantitative extraction and fractionation of humic substances (HS) in humin (C-HU), fulvic acid (C-FA), and humic acid (C-HA) were determined by differential solubility, established by the International Humic Substances Society (Swift 1996), and the labile $\mathrm{C}$ (C-labile) was performed with the methodology proposed by Mendonça and Matos (2005), determined by sample oxidation with $0.033 \mathrm{~mol} \mathrm{l}^{-1}$ potassium permanganate and the reading of the extracts in a spectrophotometer at $565 \mathrm{~nm}$.

Nitrogen from soil (N-S) and residue (N-St) was determined using the Kjeldahl method described by Black (1965). For the soybean residue treatment, it was not possible to perform the N-St analysis in the final period (48th DAI) because there was not enough plant material due to its high decomposition rate.

\subsection{Data processing and statistical analysis}

The variability of the studied properties was previously evaluated by means of descriptive statistics by calculating the 
mean, standard deviation, and minimum and maximum values.

Subsequently, the variables were subjected to multivariate exploratory analysis by hierarchical clustering and principal component methods. For the cluster analysis, a similarity matrix was constructed with the Euclidean distance and the connections of the clusters were conducted with the Ward method (Sneath and Sokal 1973). In this method, the distance between two groups is defined as the sum of squares between the two groups through all variables (Hair 2007). The Euclidean distance among accesses to the set of variables was calculated, distinguishing between the studied factors (residue types, doses, and time) and exposing the group structure contained within the data in a dendrogram.

For principal component analysis (PCA), we used the variables $\mathrm{CO}_{2}-\mathrm{C}$ emission, nitrogen soil (N-S) and residue (N-St), and carbon soil (TOC-S) and residue (TOC-St), in addition to humic substance carbon (C-HS) fractionated in fulvic acids (C-FA), humic acid (C-HA), and humin (C$\mathrm{HU}$ ). Subsequently, we scaled up the number of variables according to their characteristics to better visualize the interaction between the variables in the coordinate axes. These new axes, the eigenvectors (new variables) called principal components (PC), are generated by linear combinations of the original variables constructed from the eigenvalues of the covariance matrix (Hair 2007; Piovesan et al. 2008). In order to obtain a simpler and more parsimonious model, we used the Kaiser criterion (1958) with eigenvectors above the unit. Analyses were conducted in the STATISTICA 7.0 software (StatSoft Inc., Tulsa, OK, USA).

\section{Results}

\subsection{Effect of time on the soil $\mathrm{CO}_{2}-\mathrm{C}$ emission}

In the soil incubation, the lowest $\mathrm{CO}_{2}-\mathrm{C}$ emission occurred in the treatment without residue addition (Fig. 1) with an average from 0.1 to $0.2 \mathrm{~g} \mathrm{~m}^{-2} \mathrm{~h}^{-1}$ at the final and initial period, respectively (Tables 2 and 3 ). The addition of residue to the soil provided the formation of two distinct conditions, more pronounced in the $\mathrm{CR}$ treatment than the AR. Initially $(1,3$, and $6 \mathrm{DAI})$, there occurred an increase in the average of $\mathrm{CO}_{2}-\mathrm{C}$ emissions in the first 6 days for soybean $\left(2.0 \mathrm{~g} \mathrm{CO}_{2}-\mathrm{C} \mathrm{m}^{-2} \mathrm{~h}^{-1}\right)$, sugarcane $\left(2.0 \mathrm{~g} \mathrm{CO}_{2}-\mathrm{C} \mathrm{m}^{-2} \mathrm{~h}^{-1}\right)$, and Brachiaria residue $(1.1 \mathrm{~g}$ $\mathrm{CO}_{2}-\mathrm{C} \mathrm{m}^{-2} \mathrm{~h}^{-1}$ ) (Fig. 1 and Table 2). In the second period $(1,3$, and $6 \mathrm{DAI})$, there was an emission decay and subsequent stability after 12 days of incubation in plots with soybean $\left(1.1 \mathrm{~g} \mathrm{CO}_{2}-\mathrm{C} \mathrm{m}^{-2} \mathrm{~h}^{-1}\right)$, sugarcane $\left(0.7 \mathrm{~g} \mathrm{CO}_{2}-\mathrm{C}\right.$ $\left.\mathrm{m}^{-2} \mathrm{~h}^{-1}\right)$, and Brachiaria residue $\left(0.5 \mathrm{~g} \mathrm{CO}_{2}-\mathrm{C} \mathrm{m}^{-2} \mathrm{~h}^{-1}\right)$, as shown in Fig. 1 and Table 3.

\subsection{Effects of residue quality and quantity}

Evaluating the quantity (AR) and quality (CR) of residue added to the soil, it was found that the AR soybean residue dose presented the highest emission of accumulated $\mathrm{CO}_{2}-\mathrm{C}$ (48.57 $\left.\mathrm{g} \mathrm{kg}^{-1}\right)$, followed by sugarcane $\left(49.06 \mathrm{~g} \mathrm{~kg}^{-1}\right)$ and Brachiaria (23.30 $\mathrm{g} \mathrm{kg}^{-1}$ ), and with respective increases of $86.98,87.11$, and $72.87 \%$ compared to the control treatment (6.32 $\mathrm{g} \mathrm{kg}^{-1}$; Fig. 2).

The CR showed the highest emission of accumulated $\mathrm{CO}_{2}-$ $\mathrm{C}$ with soybean residue $\left(80.53 \mathrm{~g} \mathrm{~kg}^{-1} \mathrm{C}-\mathrm{CO}_{2}\right)$, followed by Brachiaria $\left(47.30 \mathrm{~g} \mathrm{~kg}^{-1} \mathrm{C}-\mathrm{CO}_{2}\right)$ and sugarcane $\left(33.21 \mathrm{~g} \mathrm{~kg}^{-1}\right.$ C- $\mathrm{CO}_{2}$ ) and with respective increases of $92.15,86.63$, and $80.96 \%$ compared to the control treatment $\left(6.32 \mathrm{~g} \mathrm{~kg}^{-1}\right.$; Fig. 2).

The greater decreases in TOC-St with AR doses occurred with soybean incubation, followed by Brachiaria and sugarcane residue, respectively $90.74,67.30 \mathrm{~g}$, and $73.84 \mathrm{~kg}^{-1}$ of carbon. At the CR, greater decreases were obtained from soybean, sugarcane, and Brachiaria residue, respectively $64.80,60.00$, and $45.60 \mathrm{~g} \mathrm{~kg}^{-1}$ TOC-St (Fig. 3). The higher the residue dose added to the soil, under $\mathrm{C} / \mathrm{N}$ ratio conditions ranging from 50.22 to $83.63 \mathrm{~g}$ $\mathrm{kg}^{-1}$ (Table 1), the greater the increase in the $\mathrm{CO}_{2}-\mathrm{C}$ emission.
Fig. $1 \mathrm{CO}_{2}$-C emission of soil with residue of soybean Brachiaria, sugarcane, and treatment control with two contributions of the residue crops in agronomic rate (AR) and constant rate (CR) during 48 days of incubation

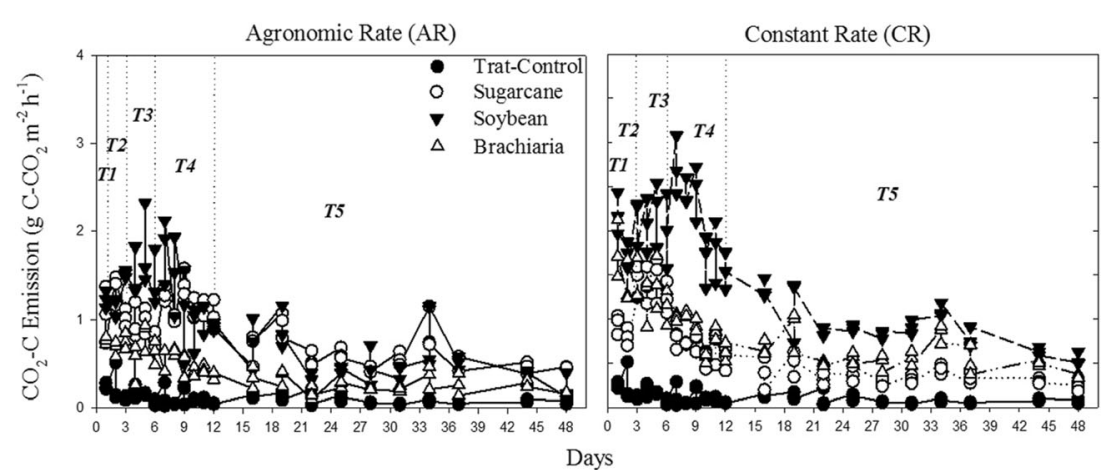


Table 2 Descriptive statistics in the initial period of variables ${ }^{\mathrm{a}}$ : humin $\mathrm{C}$ (C-HU), fulvic acid (CFA), humic acid (C-HA), watersoluble carbon (C-WSC), carbon labile (C-Labile), microbial biomass carbon (C-Mic), total carbon organic soil (TOC-S), carbon organic soil residue (TOC$\mathrm{St})$, nitrogen organic soil (N-S), nitrogen organic residue $(\mathrm{N}-\mathrm{St})$, and emission of $\mathrm{CO}_{2}-\mathrm{C}$ of soil

\begin{tabular}{lllllllll}
\hline & Mean & SD & Max & Min & Mean & SD & Max & Min \\
\hline & No residue & & & & Sugarcane & & & \\
C-HU & 12.0 & 0.7 & 13.1 & 10.9 & 12.4 & 1.2 & 14.9 & 10.0 \\
C-HA & 2.1 & 0.2 & 2.6 & 1.9 & 2.2 & 0.4 & 3.1 & 1.6 \\
C-FA & 3.5 & 0.3 & 3.8 & 3.0 & 3.5 & 1.1 & 7.5 & 1.8 \\
C-WSA & 0.2 & 0.1 & 0.4 & 0.1 & 0.2 & 0.0 & 0.2 & 0.1 \\
C-Labile & 5.2 & 0.0 & 5.2 & 5.2 & 5.2 & 0.0 & 5.2 & 5.2 \\
C-Mic & 1631.8 & 497.1 & 2336.9 & 1018.5 & 2515.5 & 1128.4 & 4954.4 & 1094.7 \\
TOC-S & 22.4 & 1.5 & 24.8 & 20.1 & 22.7 & 2.1 & 26.2 & 18.4 \\
N-S & 1.3 & 0.2 & 1.8 & 1.1 & 1.6 & 0.5 & 3.4 & 1.3 \\
TOC-St & - & - & - & - & 93.3 & 30.9 & 133.8 & 45.0 \\
N-St & - & - & - & - & 8.0 & 1.5 & 11.5 & 3.9 \\
CO-C & 0.2 & 0.5 & 1.9 & 0.8 & 2.0 & 1.3 & 9.8 & 4.6 \\
& Brachiaria & & & & Soybean & & & \\
C-HU & 12.4 & 1.1 & 14.0 & 10.6 & 12.4 & 1.1 & 14.0 & 10.0 \\
C-HA & 2.3 & 0.3 & 2.8 & 1.9 & 2.3 & 0.5 & 3.3 & 1.2 \\
C-FA & 3.4 & 0.5 & 4.2 & 2.4 & 3.7 & 0.4 & 4.8 & 3.1 \\
C-WSA & 0.2 & 0.1 & 0.3 & 0.1 & 0.2 & 0.1 & 0.4 & 0.0 \\
C-Labile & 5.2 & 0.0 & 5.2 & 5.2 & 5.2 & 0.0 & 5.2 & 5.2 \\
C-Mic & 2117.7 & 1049.7 & 3900.8 & 681.9 & 2239.6 & 865.4 & 3481.7 & 1150.1 \\
TOC-S & 23.1 & 2.8 & 26.7 & 18.0 & 23.4 & 2.2 & 26.5 & 18.9 \\
N-S & 1.5 & 0.2 & 1.8 & 1.3 & 1.7 & 0.3 & 2.2 & 1.3 \\
TOC-St & 115.5 & 30.0 & 152.4 & 54 & 87.0 & 37.9 & 135 & 24.6 \\
N-St & 7.9 & 1.8 & 11.5 & 3.1 & 10.6 & 4.4 & 19.6 & 4.9 \\
CO -C & 1.1 & 2.9 & 13.4 & 3.6 & 2.0 & 3.0 & 15.4 & 5.5 \\
\hline
\end{tabular}

${ }^{\text {a }}$ Values of C-HU, C-HA, C-FA, C-WSA, C-Labile, TOC-S, N-S, TOC-St, and N-St in $\mathrm{g} \mathrm{kg}^{-1}$. The values of CMic and emission, respectively, are in $\mu \mathrm{g} \mathrm{g}^{-1} \mathrm{ha}^{-1}$ and $\mathrm{g} \mathrm{CO}_{2}-\mathrm{C} \mathrm{m}^{-2} \mathrm{~h}^{-1}$

In soil with addition of $20 \mathrm{Mg} \mathrm{ha}^{-1}$ (AR) of sugarcane residue,
$\mathrm{C}$ loss via $\mathrm{CO}_{2}-\mathrm{C}$ emission was $72.9 \%$ from the residue decomposition. As for the doses of 8 and $5 \mathrm{Mg} \mathrm{ha}^{-1}$, respectively, of soybean and Brachiaria, $\mathrm{CO}_{2}-\mathrm{C}$ losses through the decomposition of residue are lower, respectively 53.2 and $31.5 \%$.
At the $\mathrm{CR}$ of added sugarcane residue, $\mathrm{C}$-loss through the $\mathrm{CO}_{2}-\mathrm{C}$ emission is $55.3 \%$ from the residue decomposition. For the soybean and Brachiaria residue, there was a $100 \% \mathrm{C}$ loss from the residue decomposition and 3.7 and $24.2 \%$ of $\mathrm{C}$ from the soil, respectively (Fig. 2).
Table 3 Descriptive statistics in the final period of variables ${ }^{\mathrm{a}}$ : humin $\mathrm{C}$ (C-HU), fulvic acid (C$\mathrm{FA})$, humic acid (C-HA), watersoluble carbon (C-WSC), carbon Labile (C-Labile), microbial biomass carbon (C-Mic), total carbon organic soil (TOC-S), carbon organic residue (TOC-St), nitrogen organic soil (N-S), nitrogen organic residue $(\mathrm{N}-\mathrm{St})$, and emission of $\mathrm{CO}_{2}-\mathrm{C}$ of soil

\begin{tabular}{lllllllll}
\hline & Mean & SD & Max & Min & Mean & SD & Max & Min \\
\hline & No residue & & & & Sugarcane & & & \\
C-HU & 17.5 & 0.9 & 18.8 & 16.0 & 17.0 & 2.6 & 19.2 & 10.0 \\
C-HA & 1.1 & 0.4 & 1.8 & 0.6 & 1.0 & 0.3 & 1.3 & 0.6 \\
C-FA & 2.1 & 0.3 & 2.4 & 1.7 & 1.8 & 0.5 & 2.4 & 0.5 \\
C-WSA & 0.1 & 0.0 & 0.1 & 0.0 & 0.1 & 0.0 & 0.2 & 0.0 \\
C-Labile & 5.2 & 0.0 & 5.2 & 5.2 & 5.2 & 0.0 & 5.2 & 5.2 \\
C-Mic & 1847.1 & 1023.0 & 2988.9 & & 2059.2 & 1212.4 & 4309.7 & 824.3 \\
TOC-S & 21.6 & 2.8 & 26.6 & 19.5 & 22.7 & 1.5 & 25.4 & 19.7 \\
N-S & 1.4 & 0.1 & 1.5 & 1.3 & 1.6 & 0.2 & 2.0 & 1.4 \\
TOC-St & - & - & - & - & 42.0 & 22.5 & 86.9 & 12.8 \\
N-St & - & - & - & - & 9.8 & 1.9 & 12.9 & 7.7 \\
CO-C & 0.1 & 0.3 & 1.1 & 0.4 & 0.7 & 2.0 & 8.0 & 2.0 \\
& Brachiaria & & & & & & \\
C-HU & 18.5 & 1.6 & 23.0 & 17.2 & 18.7 & 1.0 & 20.0 & 17.6 \\
C-HA & 1.0 & 0.3 & 1.3 & 0.3 & 1.1 & 0.3 & 1.5 & 0.3 \\
C-FA & 2.2 & 0.4 & 2.6 & 1.4 & 2.2 & 0.7 & 3.1 & 1.2 \\
C-WSA & 0.3 & 0.9 & 3.2 & 0.0 & 0.9 & 1.4 & 3.2 & 0.1 \\
C-Labile & 5.2 & 0.0 & 5.2 & 5.2 & 5.2 & 0.0 & 5.2 & 5.2 \\
C-Mic & 1276.1 & 359.3 & 1752.5 & 721.1 & 1560.5 & 929.6 & 3260.0 & 750.0 \\
TOC-S & 21.1 & 2.0 & 24.8 & 17.7 & 22.8 & 3.0 & 30.8 & 19.7 \\
N-S & 1.4 & 0.2 & 1.7 & 1.2 & 1.6 & 0.2 & 2.0 & 1.2 \\
TOC-St & 75.8 & 30.5 & 113.4 & 32.1 & 60.1 & 38.0 & 129.6 & 17.4 \\
N-St & 7.8 & 0.55 & 8.7 & 7.0 & - & - & - & - \\
CO - -C & 0.5 & 1.3 & 5.2 & 1.4 & 1.1 & 3.7 & 13.7 & 2.8 \\
\hline
\end{tabular}

${ }^{a}$ Values of C-HU, C-HA, C-FA, C-WSA, C-Labile, TOC-S, N-S, TOC-St, and N-St in $\mathrm{g} \mathrm{kg}^{-1}$. The values of CMic and emission, respectively, are in $\mu \mathrm{g} \mathrm{g}^{-1} \mathrm{ha}^{-1}$ and $\mathrm{g} \mathrm{CO}_{2}-\mathrm{C} \mathrm{m}^{-2} \mathrm{~h}^{-1}$ 
Fig. 2 Carbon losses (C-Losses) of residue and soil $\left(\mathrm{g} \mathrm{kg}^{-1}\right)$, and cumulative emission of $\mathrm{CO}_{2}-\mathrm{C}(\mathrm{g}$ $\mathrm{kg}^{-1}$ ) of soil with residue of soybean, Brachiaria, sugarcane, and treatment control in two contributions of the residue crops in agronomic rate (AR) and constant rate (CR) in 48 days after incubation

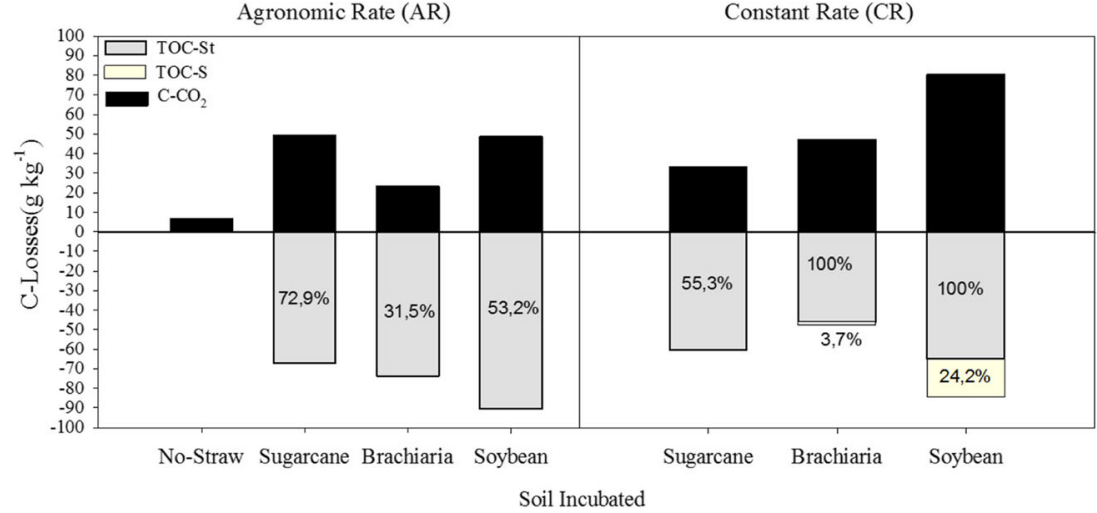

\subsection{Multivariate analyses of variables}

In the principal component analysis (PCA), there was the formation of a two-dimensional plane (Fig. 4) with three principal components (PC), PC1, PC2, and PC3, accounting for $70.02 \%$ of the original information. The first $\mathrm{PC} 1$ has $36.95 \%$ of variance, followed by CP2 with $20.67 \%$ and $\mathrm{CP} 3$ with $12.40 \%$. This result is in agreement with the criteria established by Sneath and Sokal (1973), wherein the number of PCs used in the interpretation must be such that it explains at least $70 \%$ of the total variance.

The most significant attributes retained in $\mathrm{PC} 1$ are related to the soil $\mathrm{CO}_{2}-\mathrm{C}$ emission process. The $\mathrm{C}-\mathrm{HA}$ and $\mathrm{C}-\mathrm{FA}$ are related directly (same sign) with the emission of $\mathrm{CO}_{2}$-C during the initial soil incubation period (1, 3, and $6 \mathrm{DAI})$.

The C-HU attribute is inversely related to the $\mathrm{CO}_{2}-\mathrm{C}$ emission from the soil (Table 4). The C-HU had mean values ranging from 12.0 to $12.4 \mathrm{~g} \mathrm{~kg}^{-1} \mathrm{C}$ at the initial time (Table 2) and 17.0 to $18.7 \mathrm{~g} \mathrm{C} \mathrm{kg}^{-1}$ at the end time (Table 3). In PCA, the C-HU positioned near the end of the incubation period (12 and $48 \mathrm{DAI}$ ) showed a close relation (Fig. 4). The mean values of the C-HU were above the averages obtained in the C-FA and C-HA at the two times (Tables 2 and 3).

At the initial time (Table 2), the C-FA obtained the higher average $\mathrm{C}$ amount ranging from 3.4 to $3.7 \mathrm{~g} \mathrm{~kg}^{-1}$
( \pm 0.3 to 1.1 ) when compared with the end time, 1.8 to $2.2 \mathrm{~g} \mathrm{C} \mathrm{kg}^{-1}$ ( \pm 0.3 to 0.7 ) (Table 2). Decreases were also observed for the $\mathrm{C}-\mathrm{HA}$ fraction, with averages from 2.1 to $2.3 \mathrm{~g} \mathrm{C} \mathrm{kg}^{-1}( \pm 0.3$ to 0.7$)$ at the initial time (Table 2$)$ and 1.0 to $1.1 \mathrm{~g} \mathrm{C} \mathrm{kg}^{-1}( \pm 0.3$ to 0.7$)$ at the end (Table 3 ). These variables showed high positive correlation, very close vectors at the initial time (Fig. 4).

In $\mathrm{PC} 2$, the $\mathrm{CO}_{2}-\mathrm{C}$ emission is proportionally related to the TOC-S and $\mathrm{N}$ contents, respectively, of the soil and residue (N-S and N-St). However, it is inversely related to the TOC-St (Table 4). The higher the amount of $\mathrm{N}$ in the soil and residue, as well as TOC-S, the higher the $\mathrm{CO}_{2}-\mathrm{C}$ emission. However, the TOC-St in the residue contributes to lower the $\mathrm{CO}_{2}-\mathrm{C}$ emissions.

The N-S was also retained in PC3, providing little information and no significant correlation with the other variables (Fig. 4 and Table 4).

The TOC-S showed averages ranging from 22.4 to $23.4 \mathrm{~g}$ $\mathrm{C} \mathrm{kg}^{-1}( \pm 1.5$ to 2.8$)$ in the initial period and 21.1 to $22.8 \mathrm{~g} \mathrm{C}$ $\mathrm{kg}^{-1}( \pm 1.5$ to 3.0) at the end (Tables 2 and 3). Lower C-Mic levels in the soil without added residue occurred in the two

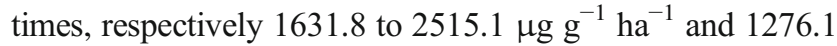
to $2059.2 \mu \mathrm{g} \mathrm{g}^{-1} \mathrm{ha}^{-1}$. When residue was added to the soil, there occurred 18.13, 39.74, and $30.32 \%$ reductions of C-Mic during the experiment, respectively, for the sugarcane, soybean, and Brachiaria residue (Tables 2 and 3).
Fig. 3 Remaining carbon from of residue of soybean, Brachiaria, and sugarcane in two contributions of the residue crops in agronomic rate (AR) and constant rate $(\mathrm{CR})$ (divided in 5 times $\mathrm{T} 1, \mathrm{~T} 2, \mathrm{~T} 3, \mathrm{~T} 4$, and $\mathrm{T} 5$, respectively $1,3,6,12$, and 48 days after incubation of soil)

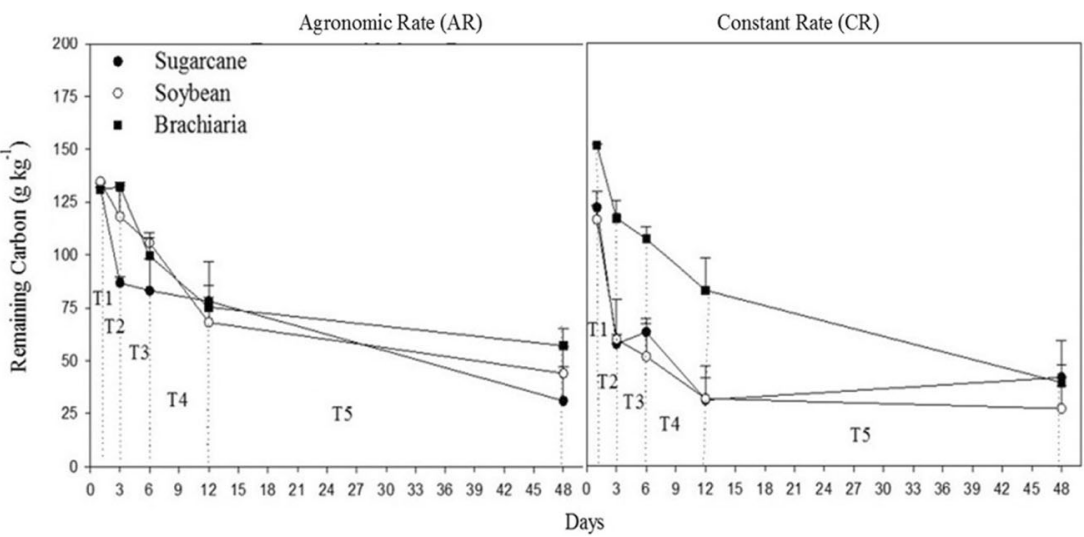



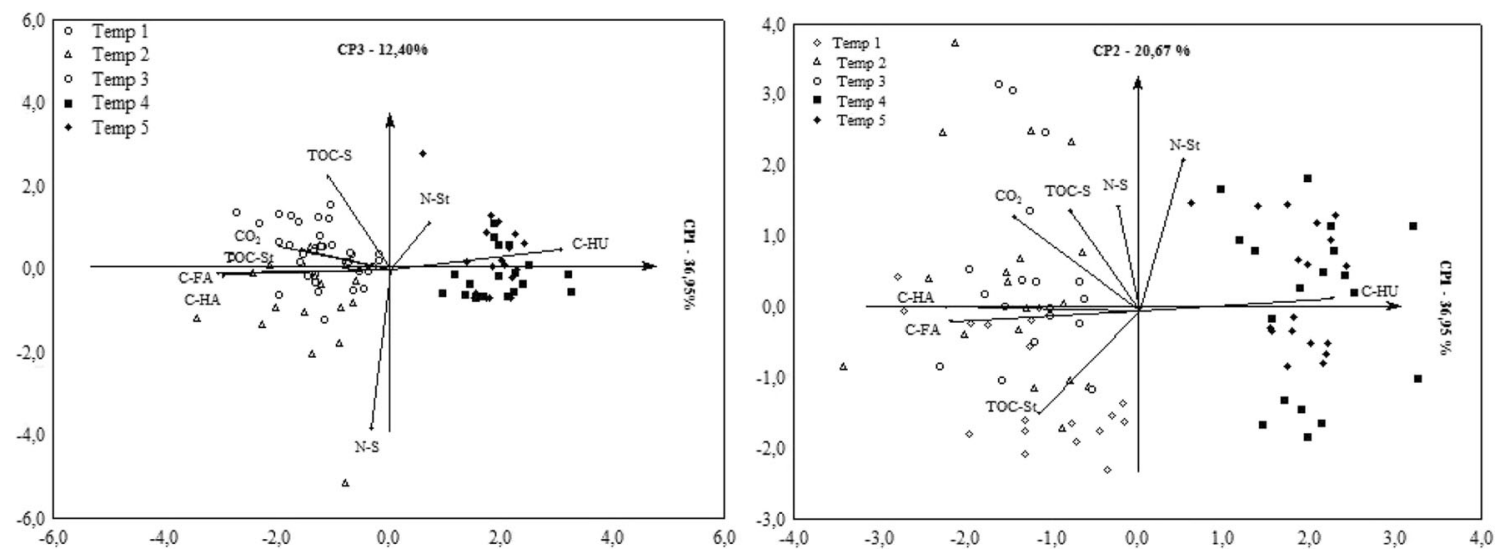

Fig. 4 Component analysis (PCA) with the variables $\mathrm{CO}_{2}-\mathrm{C}$ emission, soil organic nitrogen (N-S) and residue (N-St) and the soil organic carbon (TOC$\mathrm{S}$ ) and residue (TOC-St), humic substance carbon (C-HS) fractionated in fulvic acids (C-FA), humic acid (C-HA), and humin (C-HU)

The C-Mic showed a positive correlation with $\mathrm{CO}_{2}-\mathrm{C}$ emission $(r=0.70)$. So with increase of the $\mathrm{C}$-Mic in the soil, an increase of emission from soil occurred (Fig. 5). However, this variable was not used in the principal component since it did not retain a large amount of information as well as the Clabile.

\section{Discussion}

\subsection{Effect of residue incubation time on the $\mathrm{CO}_{2}-\mathrm{C}$ emission}

The low $\mathrm{CO}_{2}-\mathrm{C}$ emission in the treatment without residue is due to the absence of organic substrate and decreases in microbial activity. Similar results were found by Babujia et al. 2010. The emission of the $\mathrm{CO}_{2}-\mathrm{C}$ results from the decay of the soil C, mainly the C-WSC, C-HA, C-FA, TOC-S, and C-HU

Table 4 Correlation coefficient of the main components (CP1, CP2, and $\mathrm{CP} 3$ ), carbon of humin (C-HU), fulvic acid (C-FA), humic acid (C$\mathrm{HA}$ ), total organic carbon and nitrogen organic (TOC-S/N-S) and residue carbon (TOC-St), nitrogen (N-St), and emission of $\mathrm{CO}_{2}-\mathrm{C}$

\begin{tabular}{llll}
\hline Attribute & $\begin{array}{l}\mathrm{CP}^{\mathrm{a}} \\
(36.95 \%)\end{array}$ & $\begin{array}{l}\mathrm{CP}^{\mathrm{a}} \\
(20.67 \%)\end{array}$ & $\begin{array}{l}\mathrm{CP}^{\mathrm{a}} \\
(12.40 \%)\end{array}$ \\
\hline $\mathrm{C}-\mathrm{HU}$ & 0.88 & 0.06 & 0.10 \\
$\mathrm{C}-\mathrm{HA}$ & -0.87 & 0.02 & -0.02 \\
$\mathrm{C}-\mathrm{FA}$ & -0.85 & -0.05 & -0.03 \\
TOC-S & -0.31 & 0.50 & 0.46 \\
$\mathrm{~N}-\mathrm{S}$ & -0.09 & 0.53 & -0.79 \\
TOC-St & -0.45 & -0.53 & 0.10 \\
$\mathrm{~N}-\mathrm{St}$ & 0.20 & 0.77 & 0.23 \\
$\mathrm{CO}{ }_{2}-\mathrm{C}$ & -0.56 & 0.50 & 0.11 \\
\hline
\end{tabular}

Correlations in italic ( $>0.50$ in absolute value) were regarded as highly significant in the interpretation of the main significant

${ }^{a}$ These values represent the variance total in component 1 (CP1), 2 (CP2), and 3 (CP3) fractions (Badía et al. 2013; Knicker et al. 2013). The emission of soil $\mathrm{CO}_{2}-\mathrm{C}$ in the absence of substrate is inversely related to the stored organic $\mathrm{C}$ and the potential loss of soil C (Cookson et al. 1998).

The low TOC-S variation is due to its colloidal and physical stability considering the addition of all fractions with a high degree of affinity with the soil particles (Stevenson 1994). In the clay fraction, the TOC-S is stabilized primarily by its intimate association with soil minerals, which protects against biological degradation (Kaiser et al. 2002), implying greater TOC stability and consequently less significant changes.

The peaks in the $\mathrm{CO}_{2}-\mathrm{C}$ emissions from the soil with residue were for 6 days of incubation followed by an exponential decrease until the end of the experiment with 48 days of incubation. The quality and quantity of residue affects the increase of $\mathrm{CO}_{2}-\mathrm{C}$ in the first 6 days. Depending on the type of plant material, such increases can be reduced to hours

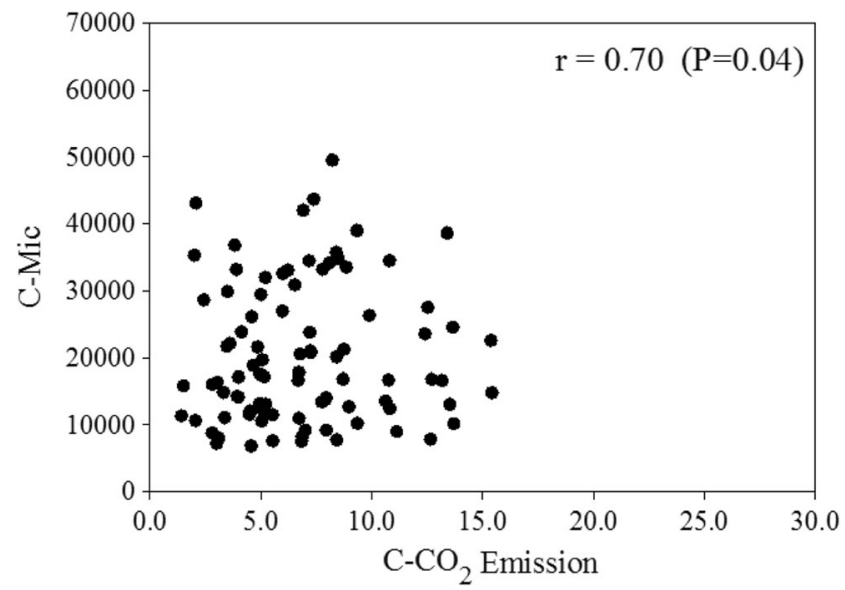

Fig. 5 Correlation between microbial biomass carbon (C-Mic) and

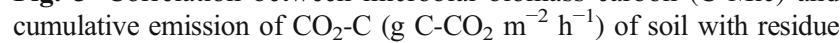
of soybean, Brachiaria, sugarcane, and treatment control in two contributions of the residue crops in agronomic rate (AR) and constant rate $(\mathrm{CR})$ in 48 days after incubation 
(Franzluebbers et al. 1994; Wang et al. 2004), considered as an initial rapid phase (Duong et al. 2009).

Soil $\mathrm{CO}_{2}-\mathrm{C}$ emission peaks after 3 days of incubation followed by an exponential decrease until the end of the experiment with 56 days of incubation were obtained by Guilou et al. (2011) working with $\mathrm{CO}_{2}-\mathrm{C}$ emission rates in Luvisol with surface addition of wheat residue. Cayuela et al. (2009), evaluating cotton wool incubated on the surface of a Regosol for 25 days, also showed that initial peak in the emission of $\mathrm{CO}_{2}-\mathrm{C}$, as did Almeida et al. (2014) incubating sugarcane residue in Latosol for 79 days.

These initial increases in the $\mathrm{CO}_{2}-\mathrm{C}$ emission are related to the addition of 5 to $20 \mathrm{Mg} \mathrm{ha}^{-1}$ of the plant material and microbial biomass activity (C-Mic), with higher expression in the treatments with soybean, Brachiaria, and sugarcane residue, respectively, of $27.13,22.94$, and $3.80 \%$ during the first period (Tables 2 and 3). Under these conditions, the $\mathrm{CO}_{2^{-}}$ $\mathrm{C}$ emission in the soil is the result of microbial respiration $(\mathrm{C}$ $\mathrm{Mic})$ with greater activity during the decomposition of organic matter (Luo et al. 2006), the C-Mic considered as a fraction of easy and rapid decomposition (Six et al. 1999; Duong et al. 2009), and with high correlation with the $\mathrm{CO}_{2}$ - $\mathrm{C}$ emissions (Cheng and Coleman 1990).

The high soil $\mathrm{CO}_{2}-\mathrm{C}$ emission contributes to the reduction of sugars, while the lignin percentage concomitantly increases (Aneja et al. 2006) the decomposition of starch and proteins as well as some carbohydrates that start at a lower rate (Gunnarsson et al. 2008), among them the C and $\mathrm{N}$ present in the compounds of fructans. Another important aspect to note is that, in general, with the addition of the residue, $\mathrm{CO}_{2}-\mathrm{C}$ emissions show a monotonic decrease over time, some more pronounced than others, which is characteristic of a behavior induced by the carbon availability of the organic matter in the labile fraction added in the beginning of the experiment $(t=0)$ (Scala et al. 2008).

The greatest increase in soil $\mathrm{CO}_{2}-\mathrm{C}$ emission with the addition of the residue causes high metabolic activity of the microorganisms which are able to degrade not only the $\mathrm{C}$ of the residues but also of the soil (Badía et al. 2013). This result is explicit in $\mathrm{PC} 1$ with inverse correlations at the final time of the $\mathrm{CO}_{2}-\mathrm{C}(r=-0.56)$ with the $\mathrm{C}-\mathrm{HU}(r=0.88)$ (Table 4), the most recalcitrant fraction of the humic substances (Duong et al. 2009; Zavalloni et al. 2011). Thus, as described by Fontaine et al. (2007), with the higher respiration, there is a decrease of the more stable SOM fractions. This is known as the priming effect because with the high soil respiration and the addition of plant residues, the breakdown of a few more resistant organic matter fractions is stimulated (Kuzyakov et al. 2000). However, residues with a high $\mathrm{C} / \mathrm{N}$ ratio and lignin quantity contribute to increases in the amount of the C-HU fraction (Martens 2000) but require a longer time (decades).
The C-HU had the highest concentration among the soil HS. This result was also found by Conteh et al. (1998), Canellas et al. (2003), Assis et al. (2006), and Rossi et al. (2011) due to increased stability caused by the strong interaction with the soil mineral fraction (Stevenson 1994).

In the $\mathrm{PC} 1$, the $\mathrm{CO}_{2}-\mathrm{C}$ emission $(r=-0.56)$ was positively correlated with C-HA $(r=-0.87)$ and C-FA $(r=-0.85)$ fractions (Table 4). Besides, the C-FA fractions have the characteristic highest mobility, solubility (Andreux and Becerra 1975), and mineralization rate among the HS fractions (Fontana et al. 2006).

Franzluebbers et al. (1994) and Wang et al. (2004) also found the decrease and subsequent stability of $\mathrm{CO}_{2}-\mathrm{C}$ emissions after 12 days of incubation in all treatments with added residue. These results are due to the high concentration of recalcitrant compounds, such as lignin and cellulose and other macromolecules (Wang et al. 2004), considered a slower phase during which the most recalcitrant fraction is decomposed (Duong et al. 2009).

\subsection{Effect of quantity and quality of the residue added to the soil on $\mathrm{CO}_{2}-\mathrm{C}$ emission}

The increase in soil $\mathrm{CO}_{2}-\mathrm{C}$ emission is closely related to the quality and quantity of residue added to soil. With the addition of $\mathrm{CO}_{2}-\mathrm{C}$, a concomitant decrease in the TOC-St occurs (Stevenson 1994). Higher reductions of TOC-St in the $20 \mathrm{Mg} \mathrm{ha}^{-1}$ dose of sugarcane residue, followed by doses of 8 and $5 \mathrm{Mg} \mathrm{ha}^{-1}$ of soybean and Brachiaria, are due to increased availability of substrate since even with the higher $\mathrm{C} / \mathrm{N}$ ratio $\left(83.6 \mathrm{~g} \mathrm{~N} \mathrm{~kg}^{-1}\right)$ and lignin $(25.8 \%)$, besides the lower $\mathrm{N}$ amount $\left(1.4 \mathrm{~g} \mathrm{~N} \mathrm{~kg}^{-1}\right)$ and crude protein $(2.50 \%)$, the sugarcane residue showed a higher amount of easily degradable material (Table 1).

Adding large amounts of residue with a high $\mathrm{C} / \mathrm{N}$ ratio causes an increase in the amount of $\mathrm{C}$ in the organic matter, compared with the addition of soybean residue with a lower $\mathrm{C} / \mathrm{N}$ (Mazzilli et al. 2014) and high quantity of crude protein (Table 1).

The quality of plant material contributed to the increased $\mathrm{CO}_{2}$-C emission in the soil from the decomposition, mainly of residue. This loss of soil $\mathrm{C}$ was more pronounced with the addition of soybean residue because of a higher concentration of labile materials or materials readily metabolizable by microbial activity (Cunha et al. 2011). This is because with the decomposition and mineralization of soybean residue, there is $\mathrm{N}$ release into soil and to microorganisms (Siczek and Lipiec 2011), increasing the biological activity due to the essential nature of $\mathrm{N}$ for the development of microorganisms, associated to the synthesis of compounds such as amino acids and enzymes (Stevenson 1994). This increases the concentrations of free sugars, starches, and pectins compared to grasses (Gunnarsson et al. 2008). 
With high soil $\mathrm{N}$ availability and unavailability of plant material, microorganisms act by decomposing the $\mathrm{C}$ present in the soil and residue, promoting higher $\mathrm{CO}_{2}-\mathrm{C}$ emissions, since the $\mathrm{CO}_{2}-\mathrm{C}$ has a high correlation with the TOC-S (Panosso et al. 2011), and about $80 \%$ of the plant material $\mathrm{C}$ is released to the atmosphere in the form of $\mathrm{CO}_{2}-\mathrm{C}$ and with an increase of $20 \%$ in the soil in different fractions and decomposition stages (Brady and Weil 2008).

Our results suggest that the quality of the residue is very important for the increase in $\mathrm{CO}_{2}-\mathrm{C}$ emission. This condition is preponderant for the time and intensity of the microbial activity in the soil, with consequent higher $\mathrm{CO}_{2}-\mathrm{C}$ emission and $\mathrm{C}$ loss from the soil and added residue. Residue added in soil with $\mathrm{C} / \mathrm{N}$ ratio under 20 decomposes rapidly, while materials with higher $\mathrm{C} / \mathrm{N}$ ratios decompose slowly and may immobilize N (Sanchez et al. 1989).

The decomposition can be evaluated with other methods like $\mathrm{N}$ concentration and $\mathrm{C} / \mathrm{N}$, cellulose, and lignin ratios as suggested by Berg (1986). Those methods can be better because the nutrient release rate during the crop residue decomposition, especially the $\mathrm{C} / \mathrm{N}$ ratio, depends on the characteristics of the species of plant (Giacomini et al. 2003).

The $18.17 \% \mathrm{~N}-\mathrm{St}$ increase from sugarcane added to the soil should be immobilized. The high $\mathrm{C} / \mathrm{N}$ ratio of sugarcane, ranging from 90 to 120 , promotes $\mathrm{N}$ immobilization in the residue in the absence of nitrogen fertilization (Meier et al. 2006). $\mathrm{N}$ immobilization in the sugarcane residue was also found by Almeida et al. (2014).

In the treatment with Brachiaria residue, there occurred consistency in the amount of TN (Tables 2 and 3) even with a high $\mathrm{C} / \mathrm{N}$ ratio (Table 1). Possibly, the constancy in TN content in Brachiaria residue (Maciel et al. 2003) may be due to allelopathic effects (Neal 1969) associated to soil microorganisms that can act in inhibiting available nutrients (Olmsted and Rice 1970).

\section{Conclusions}

The quality and quantity of residue added to soil influences the carbon sequestration and $\mathrm{C}-\mathrm{CO}_{2}$ emission. In the first 6 days of incubation, there was a higher $\mathrm{C}-\mathrm{CO}_{2}$ emission ratio with the less stable soil carbon compartments (C-HA, C-FA, $\mathrm{N}-\mathrm{S}$ ) as well as residue (TOC-St, N-St). In the final period, there is no difference between quality and quantity of residue added to soil.

Acknowledgments The authors would like to thank the following Brazilian institutions for their financial support: Fundação de Amparo à Pesquisa do Estado de Minas Gerais (FAPEMIG), Coordenação de Aperfeiçoamento de Pessoal de Nível Superior (CAPES), Conselho Nacional de Desenvolvimento Científico e Tecnológico (CNPQ), and Fundação de Amparo a Pesquisa de São Paulo (FAPESP).

\section{References}

Almeida D, Klauberg Filho O, Felipe AF, Almeida HC (2009) Carbono, nitrogênio e fósforo microbiano do solo sob diferentes coberturas em pomar de produção orgânica de maçã no sul do Brasil. Bragantia. doi:10.1590/S0006-87052009000400028

Almeida RF, Mikhael JER, Franco FO, Ribeiro BT, Ferreira AD, Mendonça ES, Wendling B (2014) $\mathrm{CO}_{2}$-C Emissions from soils incubated with sugarcane residue and nitrogen fertilizer. African Journal of Biotechology 13:3376-3384

Alvaro-Fuentes J, Paustian K (2011) Potential soil carbon sequestration in a semiarid Mediterranean agroecosystem under climate change: quantifying management and climate effects. Plant Soil 338:261272

Aneja MK, Sharma S, Fleischmann F, Stich S, Heller W, Bahnweg G, Munch JC, Schloter M (2006) Microbial colonization of beech and spruce litter - influence of decomposition site and plant litter species on the diversity of the microbial community. Microbial Ecol 52: 127-135

Andreux P, Becerra SP (1975) Fraccionamiento y caracterización del material húmico en algunos suelos de sabana de la Orinaquia Colombiana. Turrialba 25:191-198

Assis CP, Jucksch I, Sá Mendonça E, Neves JCL (2006) Carbono e nitrogênio em agregados de Latossolo submetido a diferentes sistemas de uso e manejo. Pesq Agrop Brasileira 41:1541-1550

Badía D, Martí C, Aguirre AJ (2013) Residue management effects on $\mathrm{CO}_{2}$ efflux and $\mathrm{C}$ storage in different Mediterranean agricultural soils. Sci Total Environ 465:233-239

Baker JM, Ochsner TE, Venterea RT, Griffis RP (2007) Tillage and soil carbon sequestration-what do we really know? Agriculture Ecosyst Environ 118:1-5

Balota EL, Calegari A, Nakatani AS, Coyne MS (2014) Benefits of winter cover crops and no-tillage for microbial parameters in a Brazilian Oxisol: a long-term study. Agr Ecosyst Environ 197:31-40

Barros RP (2012) Diversidade de fungos em um vertissolo com adição de vinhaça na cultura de cana-de-açúcar (Saccharum officinarum). Revista Uniabeu 5:181-196

Babujia LC, Hungria M, Franchini JC, Brookes PC (2010) Microbial biomass and activity at various soil depths in a Brazilian oxisol after two decades of no-tillage and conventional tillage. Soil Biol Biochem 42:2174-2181

Berg B (1986) Nitrogen release from litter and humus in coniferous forest soil—a mini review. Scand J Forest Res 1:359-369

Black CA (1965) Methods of soil analysis: part 2: chemical and microbiological properties. American Society of Agronomy, Madison

Bordonal RO, Figueiredo EB, Aguiar DA, Adami M, Rudorff BFT, La Scala N (2013) Greenhouse gas mitigation potential from green harvested sugarcane scenarios in São Paulo State, Brazil. Biomass Bioenerg 59:195-207

Brady NC, Weil RR (2008) The nature and properties of soils. Prentice Hall, New Jersey

Canellas LP, Velloso ACX, Marciano CR, Ramalho JFGP, Rumjanek VM, Rezende CE, Santos GA (2003) Propriedades químicas de um cambissolo cultivado com cana-de-açúcar, com preservação do palhiço e adição de vinhaça por longo tempo. Rev Bras Ciênc Solo 27:935-944

Cayuela ML, Sinicco T, Mondini C (2009) Mineralization dynamics and biochemical properties during initial decomposition of plant and animal residues in soil. Appl Soil Ecol 41:118-127

Cheng W, Coleman DC (1990) Effect of living roots on soil organic matter decomposition. Soil Biol Biochem 6:781-787

Conteh A, Blair GJ, Rochester IJ (1998) Soil organic carbon fractions in a Vertisol under irrigated cotton production as affected by burning and incorporating cotton stubble. Aust J Soil Res 36:655-667 
Cookson WR, Beare MH, Wilson PE (1998) Effects of prior crop residue management on microbial properties and crop residue decomposition. Appl Soil Ecol 7:179-188

Costa SM, Mazzola PG, Silva JCAR, Pahl R, Pessoa Jr. A, Costa SA (2013) Use of sugar cane straw as a source of cellulose for textile fiber production. Industrial Crops and Products 42(1):189-194

Cunha EQ, Stone LF, Ferreira EPB, Didonet AD, Moreira JAA, Leandro WM (2011) Sistemas de preparo dosolo e culturas de cobertura na produção orgânica de feijão e Milho. II-Atributos biológicos do solo. Rev Bras Ciênc Solo 35:603-611

Dorodnikov M, Kuzyakov Y, Fangmeier A, Wiesenberg GLB (2011) C and $\mathrm{N}$ in soil organic matter density fractions under elevated atmospheric $\mathrm{CO}_{2}$ : turnover vs. stabilization. Soil Biol Biochem 43:579-589

Duong TTT, Baumann K, Marschner P (2009) Frequent addition of wheat residue residues to soil enhances carbon mineralization rate. Soil Biol Biochem 41:1475-1482

Fontana A, Pereira MG, Loss A, Cunha TJF, Salton JC (2006) Atributos de fertilidade e frações húmicas de um Latossolo Vermelho no Cerrado. Pesq Agrop Brasileira 41:847-853

Franzluebbers K, Weaver RW, Juo ASR, Franzluebbers AJ (1994) Carbon and nitrogen mineralization from cowpea plant parts decomposing in moist and in repeatedly dried and wetted soil. Soil Biol Biochem 26:1379-1387

Gassen DN, Gassen FR (1996) Plantio direto. Passo Fundo

Giacomini SJ, Aita C, Hübner AP, Lunkes A, Guidini E, Amaral EB (2003) Liberação de fósforo e potássio durante a decomposição de resíduos culturais em plantio direto. Pesq Agrop Brasileira 38:1097-1104

Glaser B, Haumaier L, Guggenberger G, Zech W (2001) The 'Terra Preta' phenomenon: a model for sustainable agriculture in the humid tropics. Naturwissenschaften 88:37-41

Gonçalves JS, Neiva JNM, Oliveira Filho GS, Lôbo RNB (2007) Valor nutritivo de silagens de capim elefante (Pennisetum purpureum Shum) e Brachiaria decumbens contendo pedúnculo de caju (Annacardium occidentale L.) desidratado. Rev Ciênc Agron 38(2):204-209

Gunnarsson S, Marstorp H, Dahlin AS, Witter E (2008) Influence of noncellulose structural carbohydrate composition on plant material decomposition in soil. Biol Fert Soils 45:27-36

Guilou CL, Angers DA, Leterme P, Menasseri-Aurby S (2011) Differential and successive effects of residue quality and soil mineral $\mathrm{N}$ on water-stable aggregation during crop residue decomposition. Soil Biol Biochem 43:1955-1960

Hair JF (2007) Análise multivariada de dados. Bookman, Porto Alegre

Heinz R, Garbiate MV, Neto ALV, Mota LHS, Correia AMP, Vitorino ACT (2011) Decomposição e liberação de nutrientes de resíduos culturais de crambe e nabo forrageiro. Revista Ciencia Rural 41: $1549-1555$

Islam KR, Weil RR (1998) Microwave irradiation of soil for routine measurement of microbial biomass carbon. Biol Fert Soils 27: 408-416

Knicker H, González-Vila FJ, González-Vázquez R (2013) Biodegradability of organic matter in fire-affected mineral soils of Southern Spain. Soil Biol Biochem 56:31-39

Kuzyakov Y, Friedel JK, Stahr K (2000) Review of mechanisms and quantification of priming effects. Soil Biol Biochem 32:1485-1498

Piovesan P, Araújo LB, Deanddias CTS (2008) Validação cruzada com correção de autovalores e regressão isotônica nos modelos de efeitos principais aditivos e interação multiplicativa. Ciência Rural 39: 1018-1023

Embrapa - Empresa Brasileira de Pesquisa Agropecuária (2010) Sobre a Soja Safrinha. Available via DIALOG. https://www.embrapa.br/ documents/1355202/1529289/Soja_Safrinha_Embrapa.pdf of subordinate document. Accessed 15 August 2014

Embrapa_Empresa Brasileira de Pesquisa Agropecuária (1997) Manual de métodos de análise de solo. Rio de Janeiro
Embrapa—Empresa Brasileira de Pesquisa Agropecuária (2014) Sistema Brasileiro de classificação de Solos. Embrapa Solos, Rio de Janeiro

Fontaine S, Barot S, Barre P, Bdioui N, Mary B, Rumpel C (2007) Stability of organic carbon in deep soil layer controlled by fresh carbon supply. Nature 408:277-280

Kaiser K, Eusterhues K, Rumpel C, Guggenberger G, Knabner KI (2002) Stabilization of organic matter by soil minerals investigations of density and particle-size fractions from two acid forest soils. J Plant Nutr Soil Sci 165:451-459

Kurihara CH, Venegas VHA, Neves JCL, Novais RF (2013) Acúmulo de matéria seca e nutriente em soja, como variável do potencial produtivo. Revista Ceres 60:690-698

Lal R (2004) Soil carbon sequestration to mitigate climate change. Geoderma 123:1-22

Lehmann J, Rillig MC, Thies J, Masiello CA, Hockaday WC, Crowley D (2011) Biochar effects on soil biota - a review. Soil Biol Biochem 43:1812-1836

Luo Z, Hu C, Zhou J, Cen K (2006) Stability of mercury on three activated carbon sorbents. Fuel Process Technol 87:679-685

MAPA-Ministério da Agricultura, Pecuária e Abastecimento (2014) Plantio direto. Available via DIALOG. http://www.agricultura.gov. $\mathrm{br} /$ desenvolvimento-sustentavel/plantio-direto of subordinate document. Accessed 15 August 2014

Maciel CDG, Corrêa MR, Alves E, Negrisoli E, Velini ED, Rodrigues JD, Ono EO, Boaro CSF (2003) Influência do manejo da palha de capim-braquiária (Brachiaria decumbens) sobre o desenvolvimento inicial de soja (Glycine max) e amendoim-bravo (Euphorbia heterophylla). Planta daninha 21:365-373

Maheri-Sis N, Abdollahi-Ziveh B, Salamatdoustnobar R, Ahmadzadeh A, Aghajanzadeh-Golshani A, Mohebbizadeh M (2011) Determining nutritive value of soybean straw for ruminants using nylon bags technique. Pak J Nutr 10(9):838-841

Martens DA (2000) Management and crop residue influence soil aggregate stability. J Environ Qual 29:723-727

Mazzilli SR, Kemanian AR, Ernst OR, Jackson RB, Piñeiro G (2014) Priming of soil organic carbon decomposition induced by corn compared to soybean crops. Soil Biol Biochem 75:273-281

Meier EA, Thorburn PJ, Wegener MK, Basford KE (2006) The availability of nitrogen from sugarcane trash on contrasting soils in the wet tropics of North Queensland. Nutr Cycl Agroecosys 75:101-114

Mendonça ES, Matos ES (2005) Matéria Orgânica do Solo: Métodos de Análises. D\&M Gráfica e Editora Ltda, Ponte Nova

Moritsuka N, Yanai J, Mori K, Kosaki T (2004) Biotic and abiotic processes of nitrogen immobilization the soil-residue interface. Soil Biol Biochem 36:1141-1148

Neal L Jr (1969) Inhibition of nitrifying bacteria by grass and forb root extracts. Can J Botany 15:633-635

Nunes UR, Andrade Júnior VC, Silva EB, Santos NF, Costa HAO, Ferreira CA (2006) Produção de palha de plantas de cobertura e rendimento do feijão em plantio direto. Pesq Agrop Brasileira 41: 943-948

Oliveira MW, Trivelin PCO, Penatti CP, Piccolo MC (1999) Decomposição e liberação de nutrientes da palha de cana-deaçúcar em campo. Pesq Agrop Brasileira 34:2359-2362

Olmsted CE, Rice EL (1970) Relative effects of known plant inhibitors on species from first two stages of old-field succession. Southwest Nat 5:165-173

Panosso AR, Marques J, Milori DMBP, Ferraudo AS, Barbieri DM, Pereira GT, La Scala N (2011) Soil $\mathrm{CO}_{2}$ emission and its relation to soil properties in sugarcane areas under Slash-and-burn and Green harvest. Soil Till Res 111:190-196

Pereira ES, Queiroz AC, Paulino MF, Cecon PR, Valadares Filho SC, Miranda LF, Fernandes AM, Cabral LC (2000) Determinação das Frações Protéicas e de Carboidratos e Taxas de Degradação in Vitro da Cana-de-Açúcar, da Cama de Frango e do Farelo de Algodão. Rev Bras Zootec 29(6):1887-1893 
Reddy N, Yang Y (2009) Natural cellulose fibers from soybean straw. Bioresource Technol 100(1):3593-3598

Rossi CQ, Pereira MG, Giacomo SG, Betta M, Polidoro JC (2011) Frações húmicas da matéria orgânica do solo cultivado com soja sobre palha de braquiária e sorgo. Bragantia 70:622-630

Sanchez PA, Palm CA, Szott LT, Cuevas E, Lal R, Fownes JH, Hendrix P, Ikawa H, Jones S, Noordwijk M V, Uehara G (1989) Organic input management in tropical agroecosystems. In: Coleman DC, Oades JM, Uehara G (Eds.) Dynamics of soil organic matter in tropical ecosystems, Hawaii, pp 125-152

Scala NL Jr, Lopes A, Spokas K, Bolonhezi D, Archer DW, Reicosky DC (2008) Short-term temporal changes of soil carbon losses after tillage described by a first-order decay model. Soil Till Res 99:108-118

Santos EDG, Paulino MF, Queiroz DS, Valadares Filho SC, da Fonseca DM, Lana RP (2004) Avaliação de Pastagem Diferida de Brachiaria decumbens Stapf: 1. Características Químico-Bromatológicas da Forragem Durante a Seca. Revista Brasileira de Zootecnologia 33(1):203-213

Siczek A, Lipiec J (2011) Soybean nodulation and nitrogen fixation in response to soil compaction and surface residue mulching. Soil Till Res 114:50-56

Sneath PH, Sokal RR (1973) Numerical taxonomy: the principles and practice of numerical classification. Freeman, San Francisco

Stanford G, Frere MH, Shwaninger DH (1973) Temperature coefficient of soil nitrogen mineralization. Soil Sci 115:321-323

Stevenson FJ (1994) Humus chemistry: genesis, composition, reactions. John Wiley \& Sons, New York

Swift RS (1996) Organic matter characterization. In: Sparks DL, Page AL, Helmke PA, Loeppert RH, Soltanpour PN, Tabatabai MA, Johnston CT, Sumner ME (eds) Methods of soil analysis: chemical methods, part 3. Soil Science Society of America; American Society of Agronomy, Madison, pp 1011-1020

Six J, Elliott ET, Paustian K (1999) Aggregate and soil organic matter dynamics under conventional and no-tillage systems. Soil Sci Soc Am J 63:1350-1358

Six J, Frey SD, Thies RK, Batten KM (2006) Bacterial and fungal contributions to carbon sequestration in agroecosystems. Soil Sci Soc Am J 70:555-569

Torres JLR, Pereira MG, Andrioli I, Polidoro JC, Fabian AJ (2005) Decomposição e liberação de nitrogênio de resíduos culturais de plantas de cobertura em um solo de cerrado. Revista Brasileira Ciência do Solo 29:609-618

Trinsoutrot I, Recous S, Mary B, Nicolardot B (2000) C and N fluxes of decomposing ${ }^{13} \mathrm{C}$ and ${ }^{15} \mathrm{~N}$ Brassica napus L.: effects of residue composition and $\mathrm{N}$ content. Soil Biol Biochem 32:1717-1730

Urquiaga S, Bodey M, Oliveira OC, Lima E, Guimarrães DHVA (1991) Importância de não queimar a palha na cultura de cana-de-açúcar. Comunicado técnico da Empresa Nacional de Pesquisa Agropecuária-EMBRAPA 1:1-6

Vance ED, Brookes PC, Jenkinson DS (1987) An extraction method for measuring soil microbial biomass-C. Soil Biol Biochem 19:703-707

Wang WJ, Baldock JA, Dalal RC, Moody PW (2004) Decomposition of plant materials in relation to nitrogen availability and biochemistry determined by NMR and wet-chemical analysis. Soil Biol Biochem 36:2045-2058

Yeomans J, Bremner JM (1988) A rapid and precise method four routine determination of organic carbon in soil. Commun Soil Sci Plant Anal 19:1467-1476

Zavalloni C, Alberti G, Biasiol S, Delle Vedove G, Fornasier F, Liu J, Peressotti A (2011) Microbial mineralization of biochar and wheat residue mixture in soil: a short-term study. Appl Soil Ecol 50:45-51 